Biol. Stud. 2016: 10(3-4); 17-24 • DOI: https://doi.org/10.30970/sbi.1003.502

www.http://publications.Inu.edu.ua/journals/index.php/biology

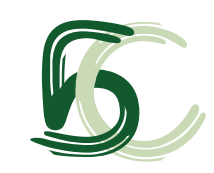

UDC 577.1: 599.232.4

\title{
GluLa-DPG-PEG600 NANOPOLYMER BINDS PROTEINS AND SPREADS TO RATS' ORGANS AND TISSUES
}

\author{
B. O. Chekh', M. V. Ferens ${ }^{2}$, Y. V. Martyn ${ }^{1}$, D. D. Ostapiv', V. V. Vlizlo \\ ${ }^{1}$ Institute of Animal Biology, NAAS of Ukraine, 38, Vasyl Stus St., Lviv 79034, Ukraine \\ e-mail: bogdanchekh@gmail.com \\ ${ }^{2}$ National University "Lviv Polytechnic", 2, St. Yura Square, Lviv 79013, Ukraine
}

In this article, we described the ability of GluLa-DPG-PEG600 nanopolymer based on the pseudopolyamino acids to bind proteins and its localization in rats organs and tissues after intravenous and intramuscular injections. By using electrophoresis in $5 \%$ polyacrylamide gel, it was found the ability of GluLa-DPG-PEG600 nanopolymer to bind bovine serum albumin (BSA). This indicates the GluLa-DPG-PEG600 is a potential transporter of proteins and their complexes. By means of fluorescent microscopy, it was found that GluLa-DPG-PEG600 nanopolymer labeled with fluorescein with BSA labeled with fluorescent Alexa Fluor 555 dye (GluLa-DPG-PEG600-F + BSA Alexa Fluor 555) localized in liver and brain on the $16^{\text {th }}$ after intramuscular injection. On the $5^{\text {th }}$ hour after intravenous injection, GluLa-DPG-PEG600-F + BSA Alexa Fluor 555 complex localized in spleen and kidney obtained. Results show a potential usefulness of GluLa-DPGPEG600 as a transporter of drugs capable of penetrating the blood-brain barrier. Localization of GluLa-DPG-PEG600-F + BSA Alexa Fluor 555 complex in spleen suggests that GluLa-DPG-PEG600 could be used as an adjuvant for development of vaccines.

Keywords: rats, nanopolymer, pseudopolyamino acids, drug transporter, adjuvant.

\section{INTRODUCTION}

At present, the main purpose of pharmacology is to make drugs that are more effective in disease treatment and are safe for human and animals. Accordingly, scientists develop new classes of polymers that are non-toxic, stable and biodegradable platforms which can be effective drug transporters. Polymers that meet these requirements can be polymers based on the pseudopolyamino acids. The main difference between polymers based on the pseudopolyamino acids and natural polyamino acids is that polymers based on the pseudopolyamino acids do not have peptide bonds in their structure that could be changed to urethane, ester, anhydrite and other chemical bonds [9]. We addressed the polymers based on the pseudopolyamino acids which have ester bonds in their structure. Particularly, lysine pseudopolyamino acids with inclusion of lactic acid providing improved cells adhesion were synthesized [2]. For tissue engineering, scientists synthesized biodegradable polymers based on the pseudopolyamino acids with

ISSN 1996-4536 (print) • ISSN 2311-0783 (on-line) • Біологічні Студії / Studia Biologica • 2016 • Том 10/№3-4 • C. 17-24 
arginine and aspartic acid in their structure $[4,6,7]$. It is were known that tyrosine-based pseudopolyamino acids polymer can transport a biologically active substances, thus, tyrosine-based pseudopolyamino acids polymers with $\mathrm{ZnO}$ can be used as potential anticancer drug $[1,5]$. Biodegradability and prolonged time of degradation are the most important characteristics for these polymers, for example, degradation time for polymers based on glycine and lactic acid is about 10 weeks $[6,7]$.

We created GluLa-DPG-PEG600 nanopolymer based on the glutamic acid that has low toxic effect in rats body [3]. We also proved the ability of this nanopolymer to penetrate mammalian cells and deposit in muscle tissues by intramuscular injection (unpublished results).

The main purpose of this work is to study the ability of GluLa-DPG-PEG600 to bind bovine serum albumin (BSA) and localization of GluLa-DPG-PEG600 complex with BSA in organs and tissues of the experimental rats.

\section{MATERIALS AND METHODS}

Matherials. We created GluLa-DPG-PEG600 nanopolymer that consist of glutamic and lauryl acids (GluLa), dipropylene glycol (DPF), and polyethylene glycol 600 (PEG600). To study the nanopolymer localization in rats body, fluorescein (F) was covalently attached to GluLa-DPG-PEG600 macromolecule and structure of the resulting nanopolymer (GluLa-DPG-PEG600-F) was confirmed by the NMR and IR spectroscopy analyses (Fig. 1).

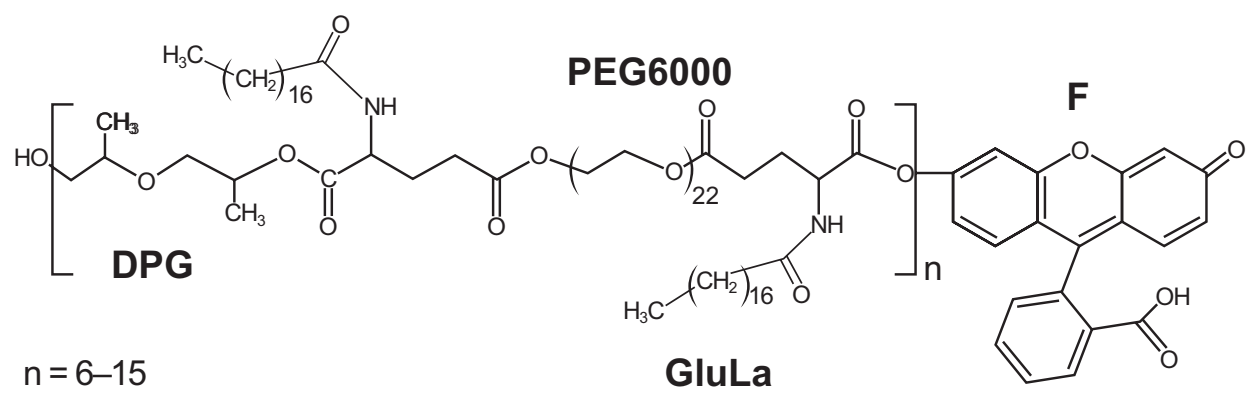

Fig. 1. Structure of nanopolyme GluLa-DPG-PEG600-F

Comments: PEG600 - polyethylene glycol; GluLa - glutamic and lauryl acids; DPG - dipropylene glycol, and F - fluorescein

Pис. 1. Структура нанополімеру GluLa-DPG-PEG600-F

Примітки: PEG600 - поліетиленгліколь; GluLa - глутамінова та лауринова кислоти; DPG - дипропіленгліколь і F - фрлуоресцеїн

Methods. Synthesis of PPAK was conducted through interaction of diol and Nprotected glutamic acid, polyoxyethylene and fluorescein (at different ratios of reagents) in a solution of benzene. The solution was cooled to $280 \mathrm{~K}$, while stirring adding the appropriate amount of 4-dimethylaminopyridine (DMAP) and dicyclohexylcarbodiimide (DCK). The reaction mixture was incubated at $288 \mathrm{~K}$ for $3 \mathrm{~h}$ and then $3 \mathrm{~h}$ at $308 \mathrm{~K}$. Dicyclohexylurea (DCC) was separated by filtration, and the polymer solution was evaporated. For purification of polyesters from catalyst residues and DCK, their solutions in benzene were prepared, washed three times with $15 \% \mathrm{NaCl}$ solution in $0,1 \mathrm{~N} \mathrm{HCl}$ and $15 \%$ aqueous $\mathrm{NaCl}$ solution to neutral $\mathrm{pH}$, after that it was dried over the magnesium sulfate, then filtered and evaporated.

ISSN 1996-4536 (print) • ISSN 2311-0783 (on-line) • Біологічні Студії / Studia Biologica • 2016 • Том 10/№3-4 • С. 17-24 
For studying the ability of nanopolymer to bind blood proteins, we tested $2 \%$ water dispersion of GluLa-DPG-PEG600 and GluLa-DPG-PEG600 with $1 \%$ water solution of BSA (molecular weight approximately $66 \mathrm{kDa}$ ) by using electrophoresis in $5 \%$ polyacrylamide gel [8].

To study the ability of the nanopolymer to spread in rats' organs and tissues, we made a complex consisting of $2 \%$ water dispersion of GluLa-DPG-PEG600-F and BSA conjugated with the Alexa Fluor 555 fluorescent dye (ThermoFisher ${ }^{\circledR}$ ) in ratio of 2.5:1 and maintained it at $+18{ }^{\circ} \mathrm{C}$ for $1 \mathrm{~h}$. We created 2 experimental and 1 control groups of animals consisting of three mature rats Rattus norvegicus var. Alba, line Wistar, (250$300 \mathrm{~g}$ ) in each group.

Rats from first experimental group were intramuscularly injected with $0.3 \mathrm{ml}$ of water dispertion of GluLa-DPG-PEG600-F + BSA Alexa Fluor 555 complexes and euthanized in $16 \mathrm{~h}$ after the injections. Rats from second experimental group were intravenously injected with $0.3 \mathrm{ml}$ of water dispertion of complexes GluLa-DPG-PEG600-F + BSA Alexa Fluor 555 and euthanized in $5 \mathrm{~h}$ after the injections. Rats of control group were intact. We prepared histological samples of spleen, liver, brain and kidney by using cryostat. Localization of GluLa-DPG-PEG600-F + BSA Alexa Fluor 555 complexes in rats organs and tissues was determined by the fluorescent microscopy with $656 \mathrm{~nm}$ wavelength using Leica DM2500 microscope and Leica Application Suite software. All animals were euthanized at soft chloroform condition. All experiments were performed in accordance with the Ministry of Education and Science of Ukraine, order No 281 from 01.11.2000, the European convention for protection of vertebrate animals used for experimental and other scientific purposes (18.03.1986), EU Directive No 609 (24.11.1986), and confirmed by protocol of bioethical expertise No $58(08.11 .2016)$ of the Institute of Animal Biology, NAAS of Ukraine.

\section{RESULTS AND DISCUSSION}

We used electrophoresis in $5 \%$ polyacrylamide gel and found that GluLa-DPG-PEG600 nanopolymer can bind BSA (Fig. 2.). This property is important for GluLa-DPG-PEG600 as a potential transporter for proteins and drugs. Furthermore, the ability of nanopolymer to bind BSA is a significant attribute to use GluLa-DPG-PEG600 as an adjuvant, since proteins are mainly used as antigens in vaccines.

Fig. 2. Polyacrylamide gel electrophoresis of BSA and GluLa-DPGPEG600 conplex with BSA

Comments: 1 - BSA; 2 - GluLa-DPG-PEG600 with BSA

Рис. 2. Електрофорез у 5\% поліакриламідному гелі БСА і БСА у комплексі з GluLa-DPG-PEG600

Примітки: 1 - BSA; 2 - GluLa-DPG-PEG600 з BSA

Histological study of liver, spleen, brain and kidney of rats revealed GluLa-DPGPEG600-F + BSA Alexa Fluor 555 complexes in all studied organs that depended on the intramuscular or intravenous injections. On the $16^{\text {th }} \mathrm{h}$ after intramuscular injection, GluLa-DPG-PEG600-F + BSA Alexa Fluor 555 complexes were localized in liver and brain tissues of the experimental group of rats (Figs. 3, 4). In liver, GluLa-DPG-PEG600-F

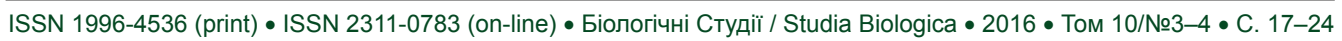


+ BSA Alexa Fluor 555 complexes were localized in liver lobules near hepatic vessels and inside it (Fig. 3, B.). Complex visualization was characterized by orange-green luminescence that matches luminescence of the Alexa Fluor 555 dye in a combination with GluLa-DPG-PEG600-F nanopolymer. This also proves that the structures with the same luminescence are lacking in liver of control group of animals (Fig. 3, A).
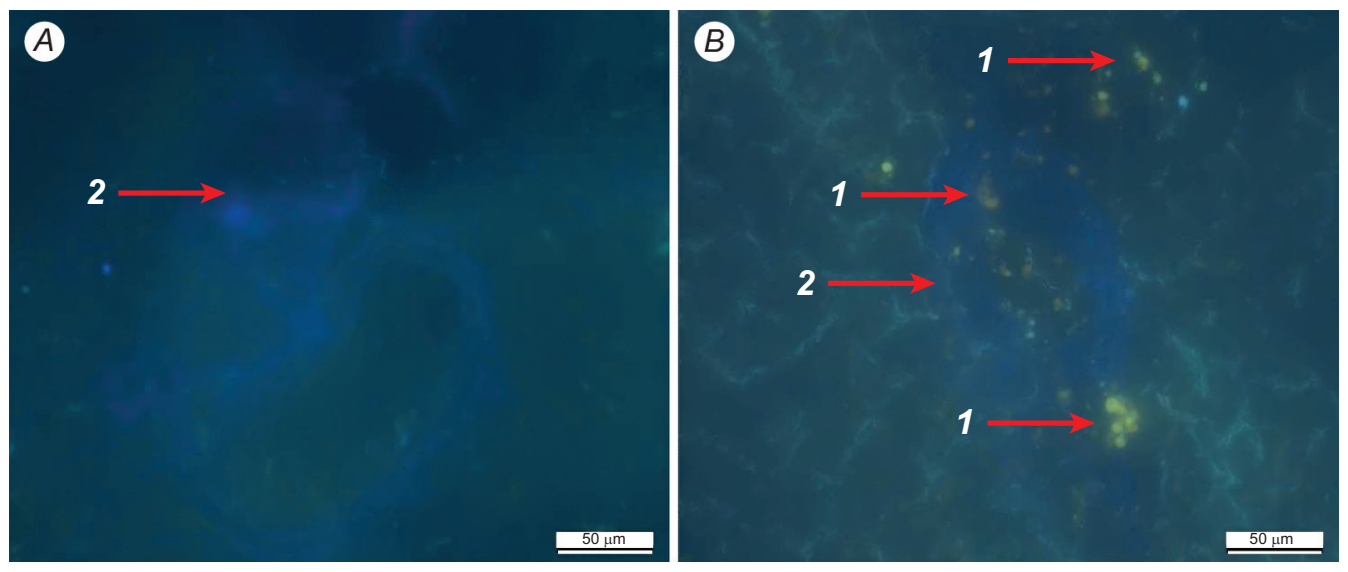

Fig. 3. Localization of GluLa-DPG-PEG600-F + BSA Alexa Fluor 555 complexes in liver of control $(A)$ and experimental $(B)$ groups of rats (luminescence microscopy, total magnification $900 \times$ )

Comments: 1 - luminescence of GluLa-DPG-PEG600-F + BSA Alexa Fluor 555 complexes; 2 blood vessel wall of liver

Рис. 3. Локалізація комплексів GluLa-DPG-PEG600-F + БCA Alexa Fluor 555 у печінці щурів, показана з використанням люмінесцентної мікроскопії гістологічних зрізів печінки контрольної $(A)$ та дослідної (B) груп щурів (збільшення у 900 разів)

Примітки: 1 - люмінесценція комплексів GluLa-DPG-PEG600-F + БCA Alexa Fluor 555; 2 - стінка судини печінки

Localization of GluLa-DPG-PEG600-F + BSA Alexa Fluor 555 complexes in liver shows the ability of GluLa-DPG-PEG600 nanopolymer, in spite of its deposit in muscles by the intramuscular injection, get into liver and engaging in xenobiotic metabolism (unpublished results) (Fig. 3, $B$ 1).

The same results were obtained by the luminescence analysis of the histological samples of rats brain. On the $16^{\text {th }} \mathrm{h}$ after intramuscular injection, GluLa-DPG-PEG600-F + BSA Alexa Fluor 555 complexes with orange luminescence were localized in brain tissues of the experimental group of rats (Fig. 4, B 1). Luminescence analysis of the histological samples of brain tissues of control group of rats revealed only catecholamines luminescence (Fig. 4, A 2).

Detection of GluLa-DPG-PEG600-F + BSA Alexa Fluor 555 complexes in brain indicates its ability to penetrate the blood-brain barrier. Earlier, it was shown that this class of nanopolymers in complex with albumins is capable of forming rod-shaped particles with a hydrodynamic diameter of $40-70 \mathrm{~nm}$ that possibly allow them to penetrate the blood-brain barrier. Theoretically this is because BSA molecules were adsorbed on the surface of GluLa-DPG-PEG600-F and acted as an additional stabilizer of a dispersed phase of the nanopolymer which reduces the linear sizes of the particles by fragmentation of large particles into smaller [10].

ISSN 1996-4536 (print) • ISSN 2311-0783 (on-line) • Біологічні Студії / Studia Biologica • 2016 • Том 10/№3-4 • С. 17-24 


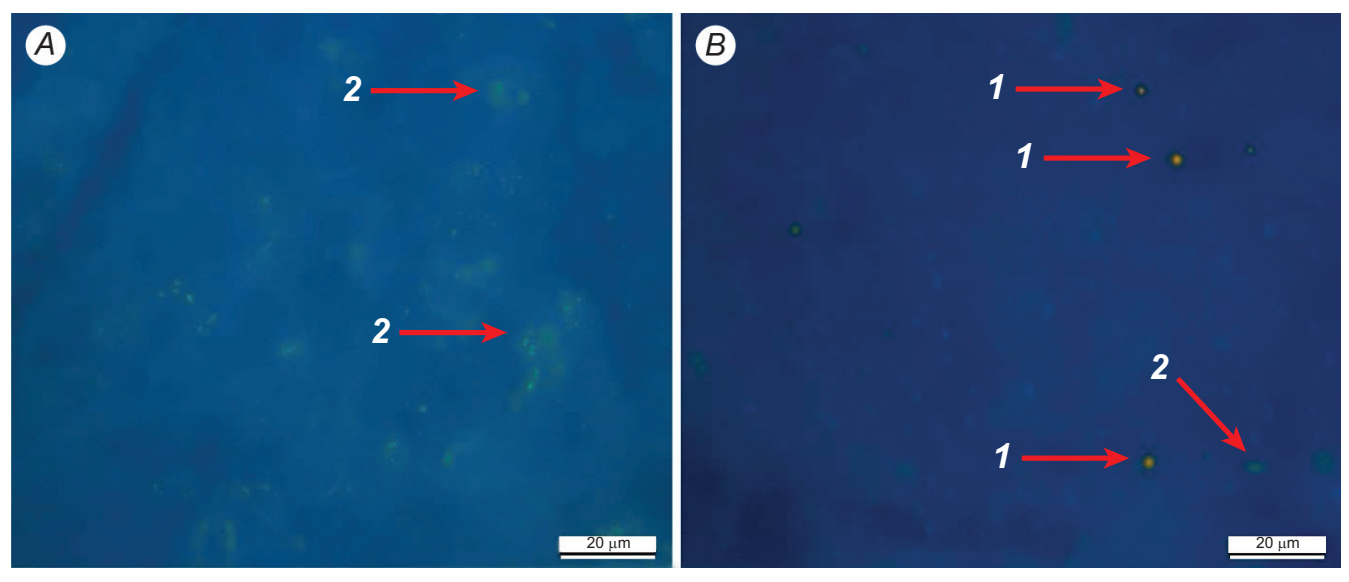

Fig. 4. Localization of GluLa-DPG-PEG600-F + БCA Alexa Fluor 555 complexes in brain of control $(A)$ and experimental $(B)$ groups of rats (luminescence microscopy, total magnification $900 \times$ )

Comments: 1 - luminescence of GluLa-DPG-PEG600-F + BSA Alexa Fluor 555 complexes; 2 - catecholamines luminescence

Рис. 4. Локалізація GluLa-DPG-PEG600-F + БCA Alexa Fluor 555 у мозку щурів, показана з використанням люмінесцентної мікроскопії гістологічних зрізів мозку контрольної $(A)$ та дослідної $(B)$ груп щурів (збільшення у 900 разів)

Примітки: 1 - люмінесценція GluLa-DPG-PEG600-F + БCA Alexa Fluor 555; 2 - люмінесценція катехоламінів у мозку

On the $5^{\text {th }} \mathrm{h}$ after intravenous injection GluLa-DPG-PEG600-F + BSA Alexa Fluor 555 complexes in rats kidney were detected. These complexes were localized in the cortical layer of kidney and in the lumens of veins in a zone of proximal convoluted tubules (Fig. 5, $B$ 1). In the control group of rats, structures with the same luminescence were not detected (Fig. 5, $A$ ).

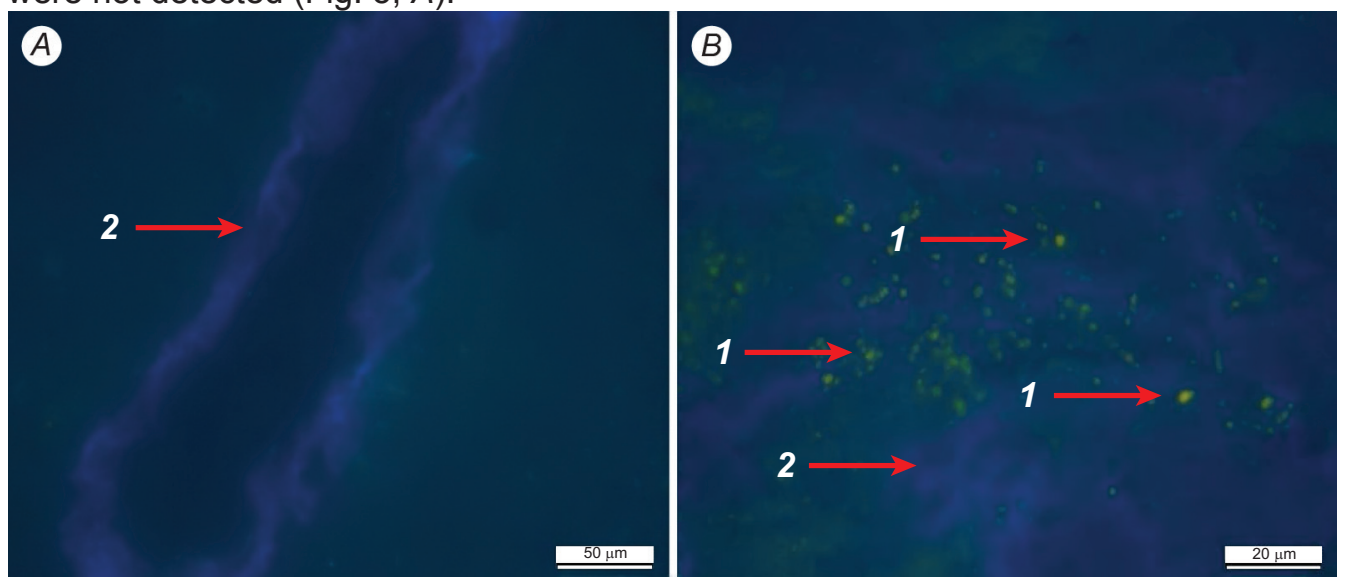

Fig. 5. Localization of GluLa-DPG-PEG600-F + BSA Alexa Fluor 555 complexes in kidney of control $(A)$ and experimental $(B)$ groups of rats (luminescence microscopy, total magnification $900 \times$ )

Comments: 1 - luminescence of GluLa-DPG-PEG600-F + BSA Alexa Fluor 555 complexes; 2 - vein in a zone of proximal convoluted tubules

Рис. 5. Локалізація комплексів GluLa-DPG-PEG600-F + БCA Alexa Fluor 555 у нирках щурів контрольної $(A)$ та дослідної $(B)$ груп (збільшення у 900 разів)

Примітки: 1 - люмінесценція комплексу GluLa-DPG-PEG600-F + БCA Alexa Fluor 555; 2 - вена в ділянці проксимальних звитих канальців мозкового шару

ISSN 1996-4536 (print) • ISSN 2311-0783 (on-line) • Біологічні Студії / Studia Biologica • 2016 • Том 10/№3-4 • C. 17-24 
Detection of GluLa-DPG-PEG600-F + BSA Alexa Fluor 555 complexes in rats kidney suggests that they are excreted by the kidney.

We also detected luminescence of GluLa-DPG-PEG600-F + BSA Alexa Fluor 555 complexes in spleen on the $5^{\text {th }} \mathrm{h}$ after intravenous injection (Fig. 6, B). In the control group of animals, structures with the same luminescence were not detected (Fig. 6, $A$ ).
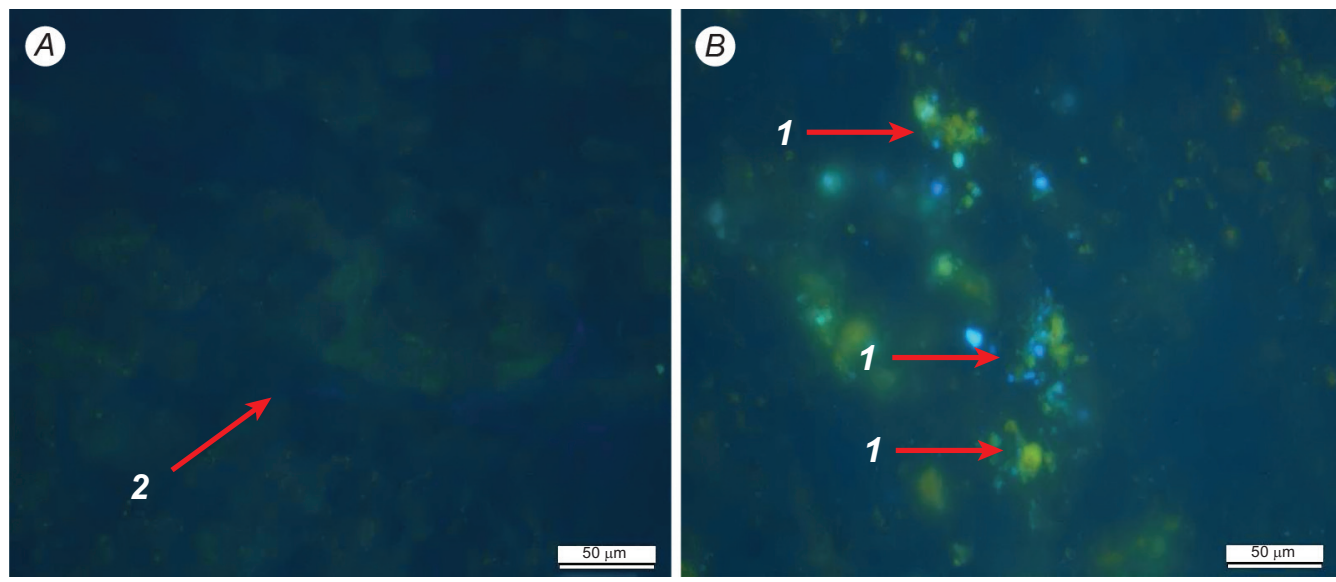

Fig. 6. Localization of GluLa-DPG-PEG600-F + BSA Alexa Fluor 555 complexes in spleen of control $(A)$ and experimental $(B)$ group of rats (luminescence microscopy, total magnification $900 \times$ )

Comments: 1 - luminescence of GluLa-DPG-PEG600-F + BSA Alexa Fluor 555 complexes; 2 lymph node

Рис. 6. Локалізація комплексів GluLa-DPG-PEG600-F + БCA Alexa Fluor 555 у селезінці щурів, показана з використанням люмінесцентної мікроскопії гістологічних зрізів селезінки контрольної $(A)$ та дослідної (B) груп щурів (збільшення у 900 разів)

Примітки: 1 - люмінесценція комплексу GluLa-DPG-PEG600-F + БCA Alexa Fluor 555; 2 - лімфатичний вузол

Localization of GluLa-DPG-PEG600-F + BSA Alexa Fluor 555 complexes in spleen confirms that GluLa-DPG-PEG600 might be used as an adjuvant for vaccine development. It is known that in spleen take place lymphocytes antigen dependent differentiation and antibody formation processes. This can provide quick and effective immune response to vaccine antigens.

\section{CONCLUSIONS}

In this study, we demonstrated that GluLa-DPG-PEG600 nanopolymer can bind bovine serum albumin which suggests GluLa-DPG-PEG600 can serve as a potential transporter of proteins and their complexes. The results of histological study based on using luminescence microscopy revealed nanopolymer localization in rats liver and brain after the intramuscular injection and in spleen and kidney after the intravenous injection. This also suggests an ability of the nanopolymer to be engaged in the xenobiotic metabolism, to penetrate blood-brain barrier, and provide its effective use as a potential drug transporter and adjuvant. 
1. Arakelova E., Khachatryan A., Karapet A. et al. Zinc oxide nanocomposites with antitumor activity. Natural Science, 2010; 2 (12): 1341-1348.

2. Barrera D. A., Zylstra E., Lansbury P. T., Langer R. Synthesis and RGD peptide modification of a new biodegradable copolymer poly(lactide acid-co-lysine). Journal of the American Chemical Society, 1993; 5: 11010-11011.

3. Chekh B. O., Ferens M. V., Martyn Y. V. et al. Functional and structural state of rats' kidneys and liver under the influence of nanopolymer based on pseudopolyamino acids. Animal Biology, 2015; 18(3): 107-113.

4. Díaz A., Katsarava R., Puiggalí J. Synthesis, Properties and Applications of Biodegradable Polymers Derived from Diols and Dicarboxylic Acids: From Polyesters to Poly(ester amide)s. International Journal of Molecular Sciences, 2014; 15: 7064-7123.

5. Sarkar D., Yang J., Sen Gupta A., Lopina S. Synthesis and characterization of L-tyrosine based polyurethanes for biomaterial applications. Journal of Biomedical Matherials Research, 2009; 90A (1): 263-271.

6. Schakenraad J.M., Dijkstra P.J. Biocompatibility of poly (DL-lactic acid / glycine) copolymers. Clin. Mater, 1991; 7: 253-269.

7. Schakenraad J.M., Nieuwenhuis P., Molenaar I. et al. In vivo and in vitro degradation of glycine /DL-lactic acid copolymers. Mater. Res, 1989; 23: 1271-1288.

8. Vlizlo V.V., Fedoruk R.S., Ratych I.B. Laboratory methods of research in biology, stockbreeding and veterinary medicine. Vlizlo V. V. (Ed.), Lviv: Spolom, 2012. 764 p. (In Ukrainian).

9. Kohn J., Langer R. A new approach to the development of biodegradable polymers for controlled release applications employing naturally occurring aminoacids. Polymeric Materials, Science and Engineering. 1984: 51: 119-121.

10. Varvarenko S., Tarnavchyk I., Voronov A. et al. Synthesis and colloidal properties of polyesters based on glutamic acids and glycols of different nature. Chemistry and Chemical Technology, 2013; 7(2): 164-168.

\title{
ЗВ'ЯЗУВАННЯ НАНОПОЛIMEPA GIULa-DPG-PEG600 3 БІЛКАМИ ТА ЙОГО ЛОКАЛІЗАЦІЯ В ОРГАНІЗМІ ЩУРІВ
}

\author{
Б. О. Чех ${ }^{1}$, М. В. Ференс ${ }^{2}$ Ю. В. Мартин ${ }^{1}$, Д. Д. Остапів ${ }^{1}$, В. В. Влізло \\ ${ }^{1} /$ нститут біології тварин НААН України, вул. В. Стуса, 38, Львів 79034, Україна \\ e-mail: bogdanchekh@gmail.com \\ ${ }^{2}$ Національний університет “Львівська політехніка”, пл. Св. Юра, 2, Львів 79013, Україна
}

У статті розглянуто здатність нанополімеру на основі псевдополіамінокислот GluLa-DPG-PEG600 зв'язуватися з білками крові та його поширення в організмі щурів за умов внутрішньом'язового і внутрішньовенного введення. 3 використанням електрофорезу в 5\% поліакриламідному гелі ми виявили здатність нанополімеру GluLa-DPG-PEG600 зв'язуватися з бичачим сироватковим альбуміном (БСА). Це, зокрема, є важливою характеристикою нанополімеру як потенційного транспортера білків і їхніх комплексів. За допомогою фрлуоресцентної мікроскопії виявлено, що нанополімер GluLa-DPG-PEG600 мічений флуоресцеїном у комплексі з БСА міченим фрлуоресцентним барвником Alexa Fluor 555 (GluLa-DPG-PEG600-F + БCA), на 16-ту годину після внутрішньом'язового введення локалізується у печінці та головному мозку щурів. На 5-ту годину у разі внутрішньовенного введення комплекс GluLa-DPG-PEG600-F + БCA Alexa Fluor 555 виявляється в селезінці та нирках щурів. Результати досліджень доводять можливість використання нанополімеру GluLa-DPG-PEG600 як потенційного транспортера лікарських засобів, що здатний

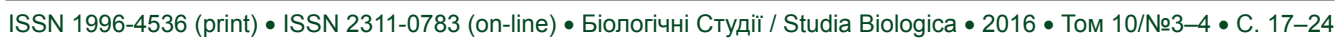


проникати крізь гематоенцефалічний бар'єр. Виявлення комплексу GluLa-DPGPEG600-F + БCA Alexa Fluor 555 у селезінці свідчить про можливе застосування нанополімеру як ад'юванта для вакцин, оскільки відомо, що в селезінці відбуваються процеси антигензалежної диференціації лімфоцитів та утворення антитіл.

Ключові слова: щурі, нанополімер, псевдополіамінокислоти, транспортер лікарських засобів, ад'ювант.

\title{
СВЯЗЫВАНИЕ НАНОПОЛИМЕРА GIULa-DPG-PEG600 С БЕЛКАМИ И ЕГО ЛОКАЛИЗАЦИЯ В ОРГАНИЗМЕ КРЫС
}

\author{
Б. О. Чех', М. В. Ференс ${ }^{2}$, Ю. В. Мартин1, Д. Д. Остапив', В. В. Влизло \\ ${ }^{1}$ Институт биологии животных НААН Украины, ул. В. Стуса, 38, Львов 79034, Украина \\ e-mail: bogdanchekh@gmail.com \\ ${ }^{2}$ Национальний университет "Львовская политехника" \\ пл. Св. Юра, 2, Львов 79013, Украина
}

В статье показана способность нанополимера на основе псевдополиаминокислот GluLa-DPG-PEG600 связываться с белками крови и его распространение в организме крыс при внутримышечном и внутривенном введении. С использованием электрофореза в 5\% полиакриламидном геле мы обнаружили способность нанополимера GluLa-DPG-PEG600 связываться с бычьим сывороточным альбумином (БСА). Это, в частности, является важной характеристикой нанополимера как потенциального транспортера белков и их комплексов. С помощью фрлуоресцентной микроскопии мы обнаружили, что нанополимер GluLa-DPG-PEG600 меченый флуоресцеином в комплексе с БСА меченым фллуресцентным красителем Alexa Fluor 555 (GluLa-DPG-PEG600-F + БCA), на 16 часов после внутримышечного введения локализируется в печени и головном мозге крыс. Через 5 часов после внутривенного введения комплекса GluLa-DPG-PEG600-F + БCA Alexa Fluor 555 он обнаруживается в селезенке и почках крыс. Результаты исследований свидетельствуют о возможности использования нанополимера GluLa-DPG-PEG600 как потенциального транспортера лекарственных средств, который способен проникать сквозь гематоэнцефралический барьер. Выявление комплекса GluLa-DPGPEG600-F + БCA Alexa Fluor 555 в селезенке свидетельствует о возможном применении нанополимера в качестве адъюванта для вакцин, поскольку известно, что в селезенке происходят процессы антигензависимой диффреренциации лимфоцитов и образование антител.

Ключевые слова: крысы, нанополимер, псевдополиаминоксилоты, транспортер лекарственных средств, адъювант.

Одержано: 14.11.2016

ISSN 1996-4536 (print) • ISSN 2311-0783 (on-line) • Біологічні Студії / Studia Biologica • 2016 • Том 10/№3-4 • С. 17-24 